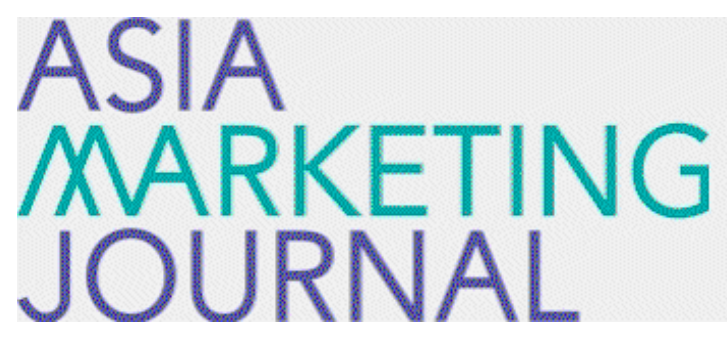

ASIA MARKETING JOURNAL

Volume 23 | Issue 4

Article 4

February 2022

\title{
Research Note: Assessing the Impact of K-pop on the Sales of Korean Brands: A Case of Automobile in the U.S. Market
}

\author{
Yayu Yuan \\ Korea University Business School Seoul, Korea, candylight1@korea.ac.kr \\ Janghyuk Lee \\ Korea University Business School Seoul, Korea, janglee@korea.ac.kr
}

Follow this and additional works at: https://amj.kma.re.kr/journal

Part of the Advertising and Promotion Management Commons, E-Commerce Commons, Marketing Commons, and the Other Business Commons

\section{Recommended Citation}

Yuan, Yayu and Lee, Janghyuk (2022) "Research Note: Assessing the Impact of K-pop on the Sales of Korean Brands: A Case of Automobile in the U.S. Market," Asia Marketing Journal: Vol. 23 : Iss. 4 , Article 4.

Available at: https://doi.org/10.53728/2765-6500.1582

This Research Notes is brought to you for free and open access by Asia Marketing Journal. It has been accepted for inclusion in Asia Marketing Journal by an authorized editor of Asia Marketing Journal. 
Research Note: Assessing the Impact of K-pop on the Sales of Korean Brands: A Case of Automobile in the U.S. Market

\section{Cover Page Footnote}

This work was supported by the Ministry of Education of the Republic of Korea and National Research Foundation of Korea (NRF-2018S1A5B6075594) as well as by Korea University Research Grant. There is no conflict of interest with any other institution. 


\title{
Research Note: Assessing the Impact of K-pop on the Sales of Korean Brands: A Case of Automobile in the U.S. Market
}

\author{
Yayu Yuan, Janghyuk Lee*
}

Korea University Business School, Seoul, South Korea

\begin{abstract}
The aim of this paper is to expand upon previous research into the country of origin effect through the use of empirical data by formulating an analysis method which allows the measurement of the extent of country of origin effect by the proxy of K-pop musicians associated with country of origin image and to propose an alternative framework which provides an explanation as to the discrepancies between empirical data and prior research. Our analysis results reveal that the impact of country of origin associated with 'PSY' and 'BTS' on the automobile sales of 'Hyundai Sonata' was significant in the U.S. market. An asymmetric country of origin effect was found vis-à-vis American and Japanese brands.
\end{abstract}

Keywords: Country of origin, Google trends search index, Contagion, PSY, BTS

\section{Introduction}

I $f$ you are a fan of BTS, chances are high that you would prefer Hyundai Sonata to Ford Fusion or Samsung Galaxy to Apple iPhone. Indeed, there is evidence to suggest that having a positive attitude towards individuals from a certain country could lead to having a positive attitude towards their country of origin and its products. Likewise, it is possible that other pop and classic musicians such as Abba, Olivia Newton John, Justin Bieber, Yoyoma, Lang, Lang Luciano Pavarotti, Placido Domingo and Sarah Chang may have indirectly contributed to sales of products from their home country through concerts, TV appearances as well as YouTube presence. In case of BTS, their fans are reported to be very actively engaging. The direct advertising effect was reported by $\mathrm{Bu}$ and Kim (2021) who measured the ad effect through SNS postings' engagement behavior As well Donabedian (2021) and Proctor (2021) elaborated the endeavor of BTS's fan called as ARMY who are actively engaged in various activities to support BTS.
However, if one were to measure the level of exposure of these musicians have attained over time and compare it with the sales of products from their home country, it would be possible to assess the extent to which the country of origin effect, hereafter $\mathrm{CO}$ effect, plays out on the real world. In this research, we provide the empirical evidence of $\mathrm{CO}$ effect by assessing the impact of K-pop musician's popularity on the sales of Korean brand in the U.S. market.

Recent discourse on the relevance of the CO effect has been focused on whether the consumer processes $\mathrm{CO}$ information in a controlled (conscious) manner or in an automatic (unconscious) manner. In Liefeld's study (2004), participants showed a very low recognition rate $(6.5 \%)$ towards the $\mathrm{CO}$ of a variety of products. Samiee et al. (2005) also reported low brand origin recognition accuracy $(35 \%)$ by participants in their study of 84 brands. Usnier and Cestre (2007) further intensified the discussion by criticizing the reflections on the relevance of $\mathrm{CO}$ brought up by Josiassen and Harzing (2008). In order to defend the relevance of $\mathrm{CO}$ effect Herz and

Received 5 January 2022; accepted 18 January 2022

Available online 11 February 2022

* Corresponding author.

E-mail addresses: candylight1@korea.ac.kr (Y. Yuan), janglee@korea.ac.kr (J. Lee). 
Diamantopoulos (2013) suggested that the mere presence effect of a country cue triggered the consumer's $\mathrm{CO}$ evaluation of the brand through an unconscious and automatic process instead of conscious and controlled one. Then Magnusson et al. (2011) flipped the angle from product to brand by showing how the consumer's image of the perceived $\mathrm{CO}$ of the brand origin affects their attitude towards the brand. To make current debates constructive, we believe that it is first necessary to address the following research questions: 1) whether the $\mathrm{CO}$ effect does exist in the case of high involvement products such as automobile, 2) whether this effect was found repeatedly with multiple musicians, 3) whether this effect was asymmetric for different brands as well as for different competing brands. We propose to do so by directly assessing the influence of $\mathrm{CO}$ perception associated with K-pop on actual purchase behavior, as depicted in Fig. 1, using empirical data.

The first type of empirical data would be one that objectively measures the strength of influence of a $\mathrm{CO}$ associated object on $\mathrm{CO}$ perception. While previous $\mathrm{CO}$ research has assessed the existence of the $\mathrm{CO}$ effect, there is lack of study but on its extent. Edwards et al. (2007) once conducted a survey among businesspeople from 450 French subsidiaries in Australia and New Zealand after the French nuclear test in 1996 to assess the degree of animosity among local consumers. However, what they measured was whether the respondents had experienced a call for boycott by diverse entities such as final consumers, distributors, and media. As such, there was no follow up causal analysis. Thanks to advances in technology, services such as Google provide ways to measure the level of interest paid to an object (e.g., 'Google Trends' search index) over time and across regions. For example, the following Fig. 2 shows the level of interest paid to 'BTS' around the world and 'BTS', 'PSY', 'Justin Bieber', and 'Taylor Swift' in the US (see Fig. 3), as provided by 'Google Trends' in between 2014 and 2021 (see Fig. 2).

The second type of data set would be purchase data collected at a submarket level, such as data on individual countries from global perspective or data on individual states from a domestic perspective, across product categories or $\mathrm{CO}$ related brands which can explain the extent of the $\mathrm{CO}$ effect through cross sectional analysis. In previous research where purchase data sets were mobilized, they were limited to either a single product category with limited choices (Maruyama and Wu 2014; Sharma 2011) or a single market without submarket level information for cross sectional analysis (Bentzen and Smith 2001). Without real sales data, measurement of the extent of the $\mathrm{CO}$ effect risks bias (and often overestimation). For example, Heslop et al. (2008) reported that negative feelings towards the French rose in Australia after the 1996 French nuclear test and that consumers' response such as willingness to buy or pride in ownership of French products dropped accordingly. According to their findings, imports from France to Australia decreased both in absolute terms and in relation to other countries, which suggested that there would be a considerable lag in recovery following the French nuclear tests (Heslop et al. 2008). However, as shown in Table 1, imports from France to Australia increased instead of decreasing through the nuclear crisis of 1996 and this increase was not substantially smaller than that of other major EU countries. Only 'primary products' from France, such as 'wine related products' recorded a $21 \%$ decrease of import in value, but this dent was quickly recovered within two years after the incident. The positive effect was reported through the lens of mega events such as Olympic games. Rose and Spiegel (2011) demonstrated the positive effect of summer Olympic games on the trade of hosting country. They showed that the act of bidding to summer Olympic games could signal the level of

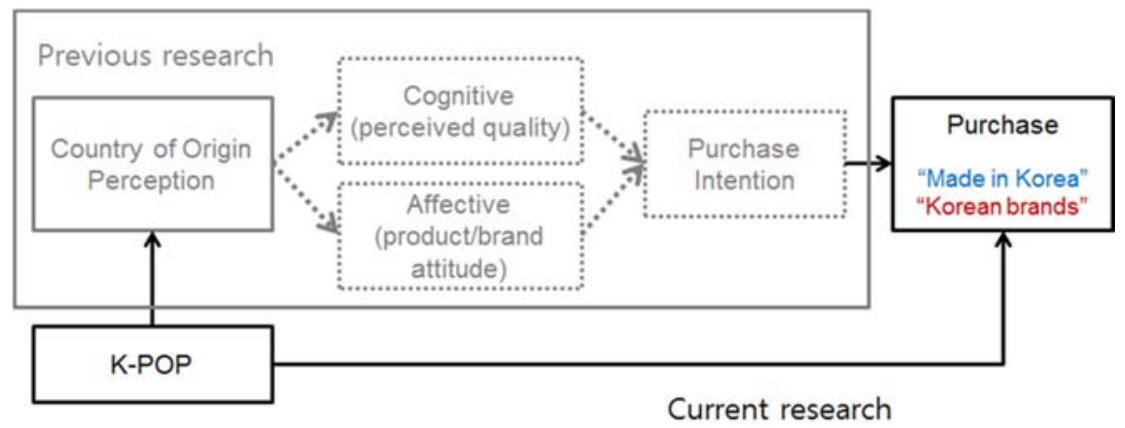

Fig. 1. A conceptual model. 

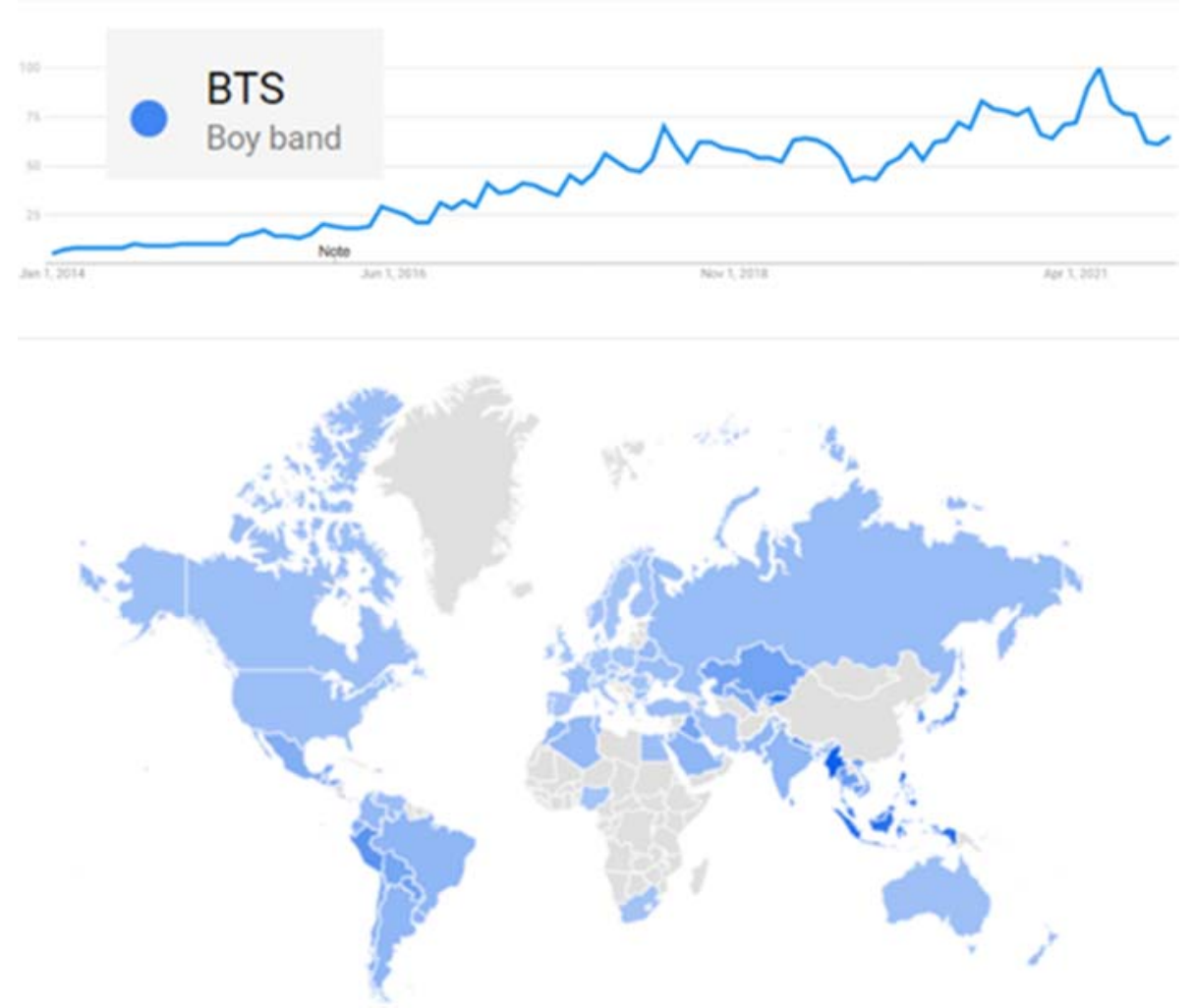

Fig. 2. 'Google Trends' search index 'BTS'.

liberalization of hosting country whose trade can benefit from it.

In the following sections, we will provide a generalizable analysis method to assess the extent of the $\mathrm{CO}$ perception effect and to test how strongly a brand is associated with its origin country regardless of brand, involvement level, product type, etc. from available sales data. Our finding aims to shed light on the strength of latent associations of corporate brands to $\mathrm{CO}$ perception, such as the asymmetric strength of association vis-à-vis US and Japanese brands, through the K-pop stars 'PSY' and 'BTS' and the temporal change in influence depending on the musicians' level of popularity as a proxy variable of $\mathrm{CO}$ by using automobile sales data in U.S. market between 2012 and 2018.

\section{Research background}

In line with our conceptual model, we explore possible logical paths from the popularity of K-pop musicians to automobile purchase behavior. The first step is to elaborate the structure of the influence of music on purchase behavior with the role of music as one of components constituting the image of country. The second step weighs the automatic information process perspective without the activation of cognitive path through which the country of origin could influence the purchase behavior consumer. Next one is to list up the measurement mobilised to capture the $\mathrm{CO}$ effect. It has been evolving from perceived quality, attitude, purchase intention to actual purchase or choice behavior. In the last one is prepared to explain the mechanism how the online search behavior influences offline purchase behavior in line with our empirical models.

\subsection{Music and country image}

Music may truly be a universal language. When listening to the same piece of music, even different listeners will show similar brain activity patterns. For example, Lu et al. (2012) reported similar patterns of neural response among untrained listeners which appeared not only in brain areas linked with sound processing, but also in regions responsible for attention, memory and movement planning.

In marketing and psychology literature, music has been considered one of the influencing factors of consumer purchase decision making through mood (Alpert and Alpert 1990; Stout and Leckenby 1988) with varying effects depending on tempo (Dowling 


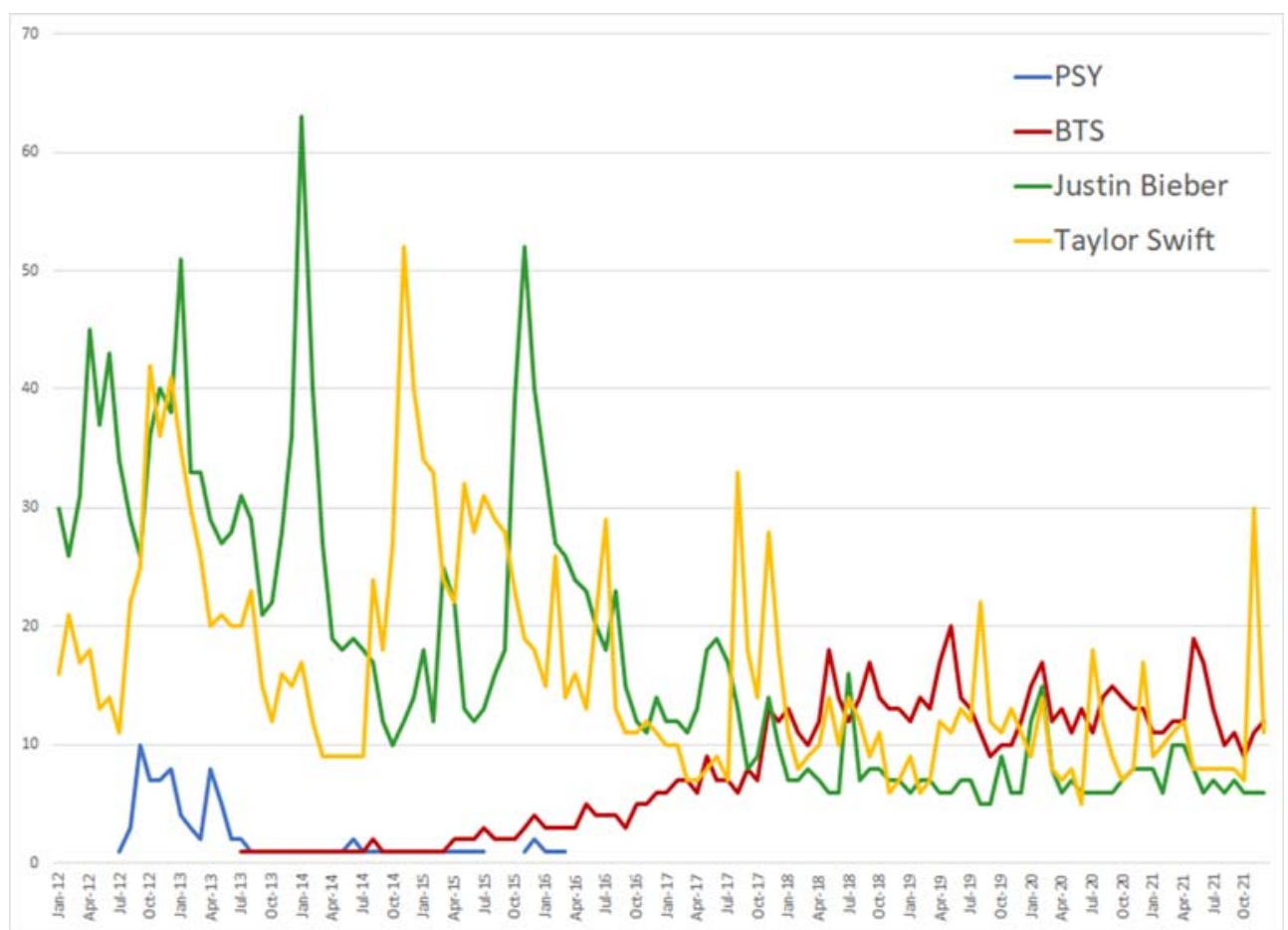

Fig. 3. Search index of PSY and BTS.

and Harwood 1986), pitch (Hevner 1937), and texture (Smith and Cunrow 1966). Park and Young (1986) examined how music, as a peripheral persuasion cue, affects the process of brand attitude formation related to involvement level and type. They found that there was a facilitative effect for the low involvement condition and a distractive effect for the high involvement condition when the type of involvement was cognitive, whereas no significant difference in effect was reported when the type of involvement was affective. Further empirical evidence of the effect of music on purchase behavior is Kellaris et al. (1993), which refined the process of using music to influence consumer behavior by showing that in case of message and thoughts congruency, message reception could be improved by increasing audience attention. Milliman (1982; 1986) also provided empirical findings related to the effect of music on purchase behavior by demonstrating that the tempo of a store's background music could affect in-store traffic flow and purchase amount in the case of supermarkets (Milliman 1982), as well as purchase amount and length of stay in the case of restaurants (Milliman 1986).

Furthermore, music has always been a key element of a country's cultural landscape, which in turn plays a significant part in defining that country's image. Wang and Lamb (1983) included cultural environment together with economic and political environment to assess the influence of country image on willingness to buy their products. Among practitioners, Future Brand includes 'culture and heritage' as one of the five dimensions (economic, political to measure brand index along with value system, quality of life, good for business, tourism) used in assessing ‘Country Brand Index' (Future Brand 2020).

Table 1. Import statistics in Australia.

\begin{tabular}{|c|c|c|c|c|c|c|c|c|}
\hline & 1993 & 1994 & 1995 & 1996 & 1997 & 1998 & 1999 & 2000 \\
\hline Total Import & 59,575 & 64,470 & 74,619 & 77,792 & 78,998 & 90,684 & 97,611 & 110,078 \\
\hline From Germany & 3383 & 3759 & 4861 & 4862 & 4558 & 5207 & 6082 & 5791 \\
\hline From U.K. & 3395 & 3698 & 4439 & 4882 & 5182 & 5593 & 5545 & 6350 \\
\hline From Italy & 1349 & 1617 & 2026 & 2231 & 2304 & 2614 & 2916 & 3043 \\
\hline From France & 1481 & 1542 & 1754 & 1867 & 1980 & 2029 & 2202 & 2228 \\
\hline 1 Primary Products & 100 & 106 & 114 & 90 & 109 & 133 & 142 & 165 \\
\hline 12 Primary products - Processed & 96 & 101 & 106 & 83 & 102 & 127 & 134 & 153 \\
\hline 1219 Preparations of food beverages \& tobacco & 75 & 81 & 83 & 64 & 77 & 97 & 106 & 118 \\
\hline
\end{tabular}

(source: Australian government department of foreign affairs and trade). 


\subsection{Automatic information processing}

Verlegh and Steenkamp (1999) summarized three types of $\mathrm{CO}$ effect: cognitive ( $\mathrm{CO}$ as quality cue to influence perceived product quality ( $\mathrm{Li}$ and Wyer 1994; Steenkamp 1989)), affective (CO provides symbolic and emotional benefits to consumers to form product/brand attitude (Batra et al. 2002; Fournier 1998), and normative (consumers hold social and personal norms related to country of origin (Shimp and Sharma 1987; Smith 1990).

A recent wave of research has raised challenging questions about the CO effect. Liefeld (2004) tackled the baseline assumption of the $\mathrm{CO}$ effect which is that consumers acquire or know the country of origin of products upon purchase and use that $\mathrm{CO}$ knowledge on purchase decision. His findings were striking as only $6.5 \%$ of purchasers (out of 1248 ) had acquired or known the $\mathrm{CO}$ of a product, and only $2.2 \%$ had taken it in consideration in making purchase decisions. In their survey on U.S. consumers Samiee et al. (2005) also found that a very high percentage of respondents did not know the country of origin of the 84 selected brands for survey $(30.8 \%-56.4 \%$ depending on its $\mathrm{CO})$ and the answer accuracy rate of brand origin was as low as $49 \%$ for US brands, which ranked highest, and $13.7 \%$ for British brands, which ranked lowest. Balabanis and Diamantopoulos (2011) also reported a similar result of low brand origin recognition for 13 consumer durable goods brands in the U.K.

On the other hand, Liu et al. (2005) conducted an experiment to show that country stereotypes can be spontaneously activated by the mere presence of $\mathrm{CO}$ information (i.e., divided attention) through the automatic information process. Herz and Diamantopoulos (2013) provided support for the mere exposure $\mathrm{CO}$ effect in experiments by validating the sequence of mere exposure triggering functional and emotional country stereotypes, which affected brand evaluation as well as purchase intention and word of mouth even in the absence of intention. Along with the stream of automatic information processing related to the $\mathrm{CO}$ effect, Magnusson et al. (2011) demonstrated the strong effect that the perceived country of brand has on brand attitudes regardless of accurate brand origin recognition.

\subsection{CO effect measurement}

Due to the choice of research methodology, such as survey and lab experiments, most of the prior research measured the $\mathrm{CO}$ effect not from actual behavior but from behavioral intention. In their meta-analysis Verlegh and Steenkamp (1999) grouped the $\mathrm{CO}$ effect in terms of product evaluation into perceived quality, attitude, and purchase intention of a product. Wang and Yang (2008) demonstrated the impact of brand personality and $\mathrm{CO}$ image on purchase intention in the context of automobile purchase by comparing the case of SinoGerman and Sino-Japanese brands. A series of experiments conducted by Veale and Quester (2009) demonstrated the $\mathrm{CO}$ effect on perceived product quality along with price in the case of wine choices. Demirbag et al. (2010) assessed the country product image effect on product preference and found that there was a negative moderating effect of materialism in three product types (trainer, laptop and pen drive). Magnusson et al. (2011) elaborated that in the product categories of TV, automobile and fashion, product country image did play a role in the consumer's brand attitude: however, the product country image of perceived $\mathrm{CO}$ and not the actual $\mathrm{CO}$ was what mattered. Table 2 summarizes the drivers and dependent measures of recent $\mathrm{CO}$ research.

Table 2. Drives and dependent variables of previous $\mathrm{CO}$ research.

\begin{tabular}{|c|c|c|c|c|}
\hline Author & Year & Independent variable & Dependent variable & Industry/product \\
\hline $\begin{array}{l}\text { Verlegh and } \\
\text { Steenkamp }\end{array}$ & 1999 & Country of origin & $\begin{array}{l}\text { Perceived quality, attitude, } \\
\text { purchase intention }\end{array}$ & Meta analysis \\
\hline Wang and Yang & 2008 & Brand personality, CO image & Purchase intention & Auto \\
\hline Veale and Quester & 2009 & Country of origin, price & Perceived product quality & Wine \\
\hline Demirbag et al. & 2010 & Country product image & Product preference & Trainer, laptop, pen drive \\
\hline Magnusson et al. & 2011 & $\begin{array}{l}\text { Product country image of } \\
\text { perceived } \mathrm{CO}\end{array}$ & Brand attitude & $\mathrm{TV}$, auto, fashion \\
\hline Sharma & 2011 & Country of origin & $\begin{array}{l}\text { Behavioral intention (trial, } \\
\text { purchase, WOM), car ownership }\end{array}$ & Auto \\
\hline Maruyama and $\mathrm{Wu}$ & 2014 & $\begin{array}{l}\text { Importance of retailer } \mathrm{CO} \text {, } \\
\text { supporting domestic retailers }\end{array}$ & Store choice & Retail \\
\hline Lee, Kim and Woo & 2014 & $\begin{array}{l}\text { YouTube pageview, } \\
\text { Google search index of K-pop }\end{array}$ & Export amount & All, Cosmetic, Apparel \\
\hline
\end{tabular}


In our knowledge, we are aware of three studies which assess $\mathrm{CO}$ effect by measuring actual purchase equivalent behavior. Sharma (2011) first measured the effect of $\mathrm{CO}$ on behavioral intention such as product trial, purchase, and word of mouth, through three moderating variables of materialism, egocentrism, and value consciousness. He then checked that there was a similar effect on the actual ownership of cars with emerging, developed, and domestic countries of origin. Maruyama and $\mathrm{Wu}$ (2014) assessed the influence of CO in choice of retailer by Chinese consumers and found that Chinese consumers tended to favor retailers of domestic origin. Lee et al. (2014) demonstrated the impact of K-pop on the export of South Korea based on two-year data. They proved the positive correlation between the YouTube pageviews of one representative K-pop channel and the Google search intensity of nine major K-pop musicians, to the exports measured from South Korea to 55 countries.

\subsection{The effect of online exposure and search on offline purchase}

In academic research, Gonipath et al. (2013) reported that the volume of pre-release blogging affected a movie's sales on release date while valence affected sales thereafter. Risselada et al. (2014) demonstrated the social influence, measured by ego network density, of mobile communication services on the adoption of offline high-involvement products (e.g., the smartphone) as consumers tended to gather information from various sources where online social media play a key role. Ghose and Yang (2009) reported that a U.S. nation-wide retailer had benefited greatly from sponsored search engine advertising, as measured in cost-per-click, even when considering conversion rates along with advertising cost. Goldfab and Tucker (2011) illustrated the substitute effect of online advertising (the case of search ad) of offline one in the context of legal service market in the U.S.

In industrial research, Google (2011) reported that there was higher sales impact from YouTube and search engine advertising than traditional media advertising on findings based on 92 cross media case studies of consumer package goods between June 2008 and March 2011. Despite having low reach $(6 \%$ for YouTube and $5 \%$ for search engines compared to $61 \%$ for TV), YouTube and search engine advertising led to higher sales lift than TV advertising, meaning that there was higher return on investment (YouTube .70, search engine 1.22 and TV .29). In follow up study, Kalyanam (2013) demonstrated the incremental offline sales driven by search advertising from a meta-analysis of experiments with 13 top U.S. retailers. Even though on average absolute sales lift was $1.46 \%$, it was relatively large compared to the compound growth rate for retail industry which was $1.55 \%$. Furthermore, sales return on ads varied from 2.17 to 14 among retailers with statistically significant effects.

\section{Empirical analysis}

\subsection{Model}

We address the unsolved problem from the study of Lee et al. (2014) where K-pop was found to have no effect on exports in the automobile industry. Possible reasons for this could be related either to the fact that the product is a high involvement product, or to the high proportion of local production which leads to local sales. A car is a very expensive product, categorized at high involvement, and consumers in general tend to take a lot of information into consideration before making their final purchase decision, so the influence of musicians would be limited even for their core fanbase. According to Court et al. (2009) U.S. consumers consider 4 models during their initial consideration set then add 2 more models during the active evaluation stage before making a decision. As a car is a very high involvement product that requires a complex buying process, mere exposures of indirect events would have limited or no effect on the purchase decision (Park and Young 1986). The second possible explanation is related to the globalization of the production process of major automobile manufacturers, which makes home country export data be inadequate to explain the $\mathrm{CO}$ perception effect. For example, the major Korean car manufacturer Hyundai Motor Corporation operates seven overseas factories which made up $86 \%$ of total production in 2012. Many of the Hyundai cars sold in the U.S. were not manufactured in South Korea but in the U.S. or in Mexico. Local auto sales generated through local or non-Korean factories were therefore not taken into consideration in the export data of South Korea.

To test the two possible explanations, we selected a homogenous automobile market, the U.S. market, and assessed the $\mathrm{CO}$ perception effects in association with K-pop across regions (its 50 states and Washington D.C.). We mobilized auto retail sales data (the number of units purchased by individual consumers) in U.S. market and the Google search index of the K-pop musicians PSY and BTS. Our baseline model (M1) demonstrates how the share of 
sales of one automobile brand (see Table 3) is influenced by its search share. The search share of focal automobile brand can represent relatively the magnitude of its marketing activities (Maltby 2014). This search share is used in the main model (M2) as a control variable of relative marketing activities of the focal automobile brand. In the main model (M2) the Google search index of two musicians was added to test the influence of the musician's popularity on the sales of share of automobile.

(M1) Automobile sales share $=\mathrm{b} 0+\mathrm{b} 1$ Automobile search share

(M2) Automobile sales share $=\mathrm{b} 0+\mathrm{b} 1$ Automobile search share + b2 Search PSY/BTS

In previous research Heslop et al. (2008) reported how the effect of $\mathrm{CO}$ can change in relation to an event by seeing how French nuclear test in Polynesian atoll near Australia affected export from the perpetrator of the event, France, to the country affected by the event, Australia. While Heslop et al.'s study deals with the repercussions of a negative effect, the case of PSY and BTS is the opposite as their popularity might have positively influenced South Korean product sales overseas.

\subsection{Data and measurement}

The sales data set was provided by one of the major market research companies in charge of the automobile industry. We did not include fleet sales into our analysis, which are related to business-tobusiness type sales, as its sales data is in general

Table 3. Sales share of Sonata and Optima.

\begin{tabular}{llllll}
\hline Period & \multicolumn{2}{l}{ Hyundai Sonata } & & \multicolumn{2}{l}{ Kia Optima } \\
\cline { 2 - 3 } \cline { 5 - 6 } & $\begin{array}{l}\text { vs. } 5 \\
\text { brands }\end{array}$ & $\begin{array}{l}\text { vs. 2 US } \\
\text { brands }\end{array}$ & & $\begin{array}{l}\text { vs. 5 } \\
\text { brands }\end{array}$ & $\begin{array}{l}\text { vs. 2 US } \\
\text { brands }\end{array}$ \\
\hline $2012 \mathrm{H} 2$ & 0.129 & 0.392 & & 0.104 & 0.337 \\
$2013 \mathrm{H} 1$ & 0.106 & 0.306 & & 0.097 & 0.284 \\
$2013 \mathrm{H} 2$ & 0.103 & 0.304 & & 0.103 & 0.300 \\
$2014 \mathrm{H} 1$ & 0.109 & 0.313 & & 0.101 & 0.292 \\
$2014 \mathrm{H} 2$ & 0.109 & 0.336 & & 0.099 & 0.308 \\
$2015 \mathrm{H} 1$ & 0.116 & 0.318 & 0.098 & 0.278 \\
$2015 \mathrm{H} 2$ & 0.110 & 0.322 & 0.098 & 0.293 \\
$2016 \mathrm{H} 1$ & 0.101 & 0.273 & & 0.086 & 0.238 \\
$2016 \mathrm{H} 2$ & 0.099 & 0.288 & & 0.089 & 0.261 \\
$2017 \mathrm{H} 1$ & 0.103 & 0.304 & & 0.092 & 0.276 \\
$2017 \mathrm{H} 2$ & 0.092 & 0.290 & 0.075 & 0.243 \\
$2018 \mathrm{H} 1$ & 0.102 & 0.329 & 0.086 & 0.289 \\
$2018 \mathrm{H} 2$ & 0.099 & 0.352 & 0.088 & 0.319 \\
Min & 0.092 & 0.273 & 0.075 & 0.238 \\
Max & 0.129 & 0.392 & 0.104 & 0.337 \\
Average & 0.106 & 0.318 & 0.094 & 0.286 \\
\hline
\end{tabular}

counted by the location of buyer companies and not by the location of end user customers of rental or lease service. Leading brands in mid-size sedan category: Two American (Chevrolet Malibu and Ford Fusion), three Japanese (Honda Accord, Nissan Altima and Toyota Camry) and two Korean brands (Hyundai Sonata and Kia Optima) were included in our analysis. The search data set was downloaded from 'Google Trends' service that is available for public. Automobile brands mobilized in our analysis were categorized as topic 'mid-size car' or 'intermediate': 'Hyundai Sonata', 'Kia Optima', 'Honda Accord', 'Nissan Altima', 'Toyota Camry', 'Chevrolet Malibu', and 'Ford Fusion'.

The share of a brand was computed as the focal brand's sales or search divided by the sum of listed brands (5 brands case: Accord, Altima, Camry, Fusion, and Malibu, 2 US brands case: Fusion and Malibu). The sales share of Hyundai Sonata varies between $9.2 \%$ and $12.9 \%$ with the average of $10.6 \%$ and that of Kia Optima does between $7.5 \%$ and $10.4 \%$ with the average of $9.4 \%$ in 5 brands case.

For the $\mathrm{CO}$ perception associated object we selected two K-pop musicians 'PSY' and 'BTS' whose possible association strength with South Korea is represented here by the Google search index. PSY became popular in U.S. during the second half of 2012 thanks to smash hit of his first international single 'Gangnam style' and his popularity continued through the first half of 2013 (he released another single 'Gentleman' April 2013), before dropping flat in the second half of 2013. The current internationally known group, BTS, debuted in 2014 and gained popularity gradually through series of hit songs. They overtook the search index popularity of Justin Bieber and Taylor Swift in U.S. January 2018 as they started appearing on Billboard rankings.

\subsection{Analysis results}

Our analysis is conducted over a seven-year period (the second half of 2012 and the second half of 2018) divided into 6-month subperiods to assess the $\mathrm{CO}$ effect of K-pop musicians on sales. Our baseline model (M1) in Table 4 shows consistently the significant effect of automobile brand's online search share on its sales share across states in U.S. over all periods. It confirms the consumer decision journey concept (Court et al. 2009) as the active evaluation of product through search on Google is transformed into the sales. Between the two brands 'Hyundai Sonata' shows a larger magnitude of search effect on sales represented by 'b1 co-efficient' (average of 0.5530 compared to that of 'Kia 
Table 4. Search effect on sales (vs. 5 brands).

\begin{tabular}{|c|c|c|c|c|c|c|c|c|c|c|}
\hline \multirow[t]{3}{*}{ Period } & \multicolumn{5}{|c|}{ Hyundai Sonata } & \multicolumn{5}{|l|}{ Kia Optima } \\
\hline & \multicolumn{2}{|l|}{ b0 } & \multicolumn{2}{|l|}{ b1 } & \multirow[t]{2}{*}{ R2 } & \multicolumn{2}{|l|}{ b0 } & \multicolumn{2}{|l|}{ b1 } & \multirow[t]{2}{*}{$\mathrm{R} 2$} \\
\hline & co-efficient & p-value & co-efficient & p-value & & co-efficient & $\mathrm{p}$-value & co-efficient & p-value & \\
\hline $2012 \mathrm{H} 2$ & 0.0304 & 0.11 & 0.6096 & $<0.01$ & 0.381 & 0.0196 & 0.31 & 0.5692 & $<0.01$ & 0.291 \\
\hline 2013H1 & 0.0301 & 0.20 & 0.4510 & $<0.01$ & 0.187 & 0.0247 & 0.12 & 0.5244 & $<0.01$ & 0.317 \\
\hline $2013 \mathrm{H} 2$ & 0.0114 & 0.55 & 0.5942 & $<0.01$ & 0.337 & 0.0392 & 0.01 & 0.5039 & $<0.01$ & 0.287 \\
\hline 2014H1 & -0.0038 & 0.84 & 0.6346 & $<0.01$ & 0.428 & 0.0308 & 0.04 & 0.4619 & $<0.01$ & 0.346 \\
\hline $2014 \mathrm{H} 2$ & 0.0116 & 0.45 & 0.6293 & $<0.01$ & 0.471 & 0.0527 & $<0.01$ & 0.3318 & $<0.01$ & 0.249 \\
\hline 2015H1 & 0.0429 & 0.08 & 0.4466 & $<0.01$ & 0.160 & 0.0508 & 0.01 & 0.2980 & 0.01 & 0.127 \\
\hline $2015 \mathrm{H} 2$ & 0.0261 & 0.10 & 0.5069 & $<0.01$ & 0.383 & 0.0337 & 0.02 & 0.4412 & $<0.01$ & 0.327 \\
\hline 2016H1 & 0.0004 & 0.98 & 0.5870 & $<0.01$ & 0.366 & -0.0010 & 0.95 & 0.5065 & $<0.01$ & 0.420 \\
\hline $2016 \mathrm{H} 2$ & 0.0065 & 0.77 & 0.5661 & $<0.01$ & 0.266 & 0.0127 & 0.45 & 0.4521 & $<0.01$ & 0.307 \\
\hline 2017H1 & 0.0048 & 0.77 & 0.5995 & $<0.01$ & 0.433 & 0.0078 & 0.70 & 0.5160 & $<0.01$ & 0.268 \\
\hline 2017H2 & -0.0005 & 0.97 & 0.5988 & $<0.01$ & 0.538 & 0.0180 & 0.32 & 0.3509 & $<0.01$ & 0.175 \\
\hline 2018H1 & 0.0014 & 0.94 & 0.5326 & $<0.01$ & 0.390 & 0.0424 & 0.01 & 0.2379 & $<0.01$ & 0.143 \\
\hline $2018 \mathrm{H} 2$ & 0.0245 & 0.11 & 0.4328 & $<0.01$ & 0.341 & 0.0350 & 0.06 & 0.3586 & $<0.01$ & 0.150 \\
\hline Min & & & 0.4328 & & 0.160 & & & 0.2379 & & 0.127 \\
\hline Max & & & 0.6346 & & 0.538 & & & 0.5692 & & 0.420 \\
\hline Average & & & 0.5530 & & 0.360 & & & 0.4271 & & 0.262 \\
\hline
\end{tabular}

Optima', 0.4271). It can be directly interpreted as Hyundai Sonata sales was more substantially influenced by its search share than 'Kia Optima' as well as a better model fit.

As the popularity of K-pop musicians is added into our baseline model (M1), we assess the effect of K-pop musician on the sales share under the control of the search share of automobile brands. In case of PSY, it provides a positive effect on the sales share of 'Hyundai Sonata' with significance at $\alpha=10 \%$ over two periods, the second half of 2012 and the first half of 2013, when the search level of PSY reached $18.7 \%(2012 \mathrm{H} 2)$ and $14.6 \%(2013 \mathrm{H} 1)$ of Justin Bieber and Taylor Swift considered as a benchmark in terms of popularity measured as search index. It means the sales share of 'Hyundai Sonata' was relatively larger in the states where 'PSY' was more popular than other states. In a state where PSY was more popular, more consumers showed their interest to PSY, a Korean musician. Their elevated interest in PSY possibly influenced their automobile purchase in favor of 'Hyundai Sonata' through two cognitive and affective paths. His impact was more salient in the case of comparison with two US brands: 'Chevrolet Malibu' and 'Ford Fusion' demonstrated in Tables 5 and 6. The asymmetric effects between 5 brands and 2 US brands cases would be caused by the fact that the size of consumer segments considering Korean and US brands together (put them into the choice set of purchase) would be larger than the segment considering Korean and Japanese brands together. In case of 'Kia Optima', we were not able to find any significant CO effect in case of 5 brands. However, in 2 US brands case, it showed a positive and slightly significant effect in the first half of 2013 ( $p$-value of 0.18 ) in Table 6.

For BTS, we conducted the same analysis with 5 brands, but no significant and positive effect was found at $\alpha=10 \%$. In 2015 first half with the coefficient of 0.0434 and 2016 first half with the coefficient of 0.0492 , their effect was positive and closely significant at $\alpha=10 \%$ ( $p$-value of 0.16 and 0.12) for 'Hyundai Sonata'. As for 'Kia Optima', no positive and significant effect was found in Table 7.

As the analysis scope is geared down to the comparison with 2 US brands instead of all 5 brands, the effect of BTS search on the share of 'Hyundai Sonata' becomes consistently positive across periods. In the first half of 2015 with the co-

Table 5. PSY effect on sales (vs. 5 brands).

\begin{tabular}{|c|c|c|c|c|c|c|c|c|}
\hline \multirow[t]{3}{*}{ Period } & \multicolumn{4}{|c|}{ Hyundai Sonata } & \multicolumn{4}{|c|}{ Kia Optima } \\
\hline & \multirow[t]{2}{*}{$\overline{\text { M1_R2 }}$} & \multicolumn{2}{|l|}{ b2 } & \multirow[t]{2}{*}{$\mathrm{R} 2$} & \multirow[t]{2}{*}{ M1_R2 } & \multicolumn{2}{|l|}{$\mathrm{b} 2$} & \multirow[t]{2}{*}{$\mathrm{R} 2$} \\
\hline & & co-efficient & p-value & & & co-efficient & $\mathrm{p}$-value & \\
\hline $2012 \mathrm{H} 2$ & 0.381 & 0.1030 & $<0.01$ & 0.467 & 0.291 & -0.0144 & 0.61 & 0.295 \\
\hline $2013 \mathrm{H} 1$ & 0.187 & 0.0747 & 0.10 & 0.231 & 0.317 & 0.0175 & 0.56 & 0.322 \\
\hline $2013 \mathrm{H} 2$ & 0.337 & 0.0099 & 0.75 & 0.338 & 0.287 & -0.0362 & 0.19 & 0.312 \\
\hline
\end{tabular}

*b2 co-efficient is multiplied by 100 for the scale issue. 
Table 6. PSY effect on sales (vs. 2 US brands).

\begin{tabular}{|c|c|c|c|c|c|c|c|c|}
\hline \multirow[t]{3}{*}{ Period } & \multicolumn{4}{|c|}{ Hyundai Sonata } & \multicolumn{4}{|c|}{ Kia Optima } \\
\hline & \multirow[t]{2}{*}{ M1_R2 } & \multicolumn{2}{|l|}{ b2 } & \multirow[t]{2}{*}{$\mathrm{R} 2$} & \multirow[t]{2}{*}{ M1_R2 } & \multicolumn{2}{|l|}{ b2 } & \multirow[t]{2}{*}{$\mathrm{R} 2$} \\
\hline & & co-efficient & p-value & & & co-efficient & $\overline{p \text {-value }}$ & \\
\hline $2012 \mathrm{H} 2$ & 0.588 & 0.3150 & $<0.01$ & 0.653 & 0.545 & 0.0558 & 0.50 & 0.550 \\
\hline 2013H1 & 0.504 & 0.2300 & 0.05 & 0.542 & 0.442 & 0.1160 & 0.18 & 0.462 \\
\hline $2013 \mathrm{H} 2$ & 0.660 & -0.0550 & 0.50 & 0.663 & 0.463 & -0.0407 & 0.54 & 0.467 \\
\hline
\end{tabular}

*b2 co-efficient is multiplied by 100 for the scale issue.

efficient of 0.137 and the first half of 2016 with the co-efficient of 0.152 their effect was significant at $\alpha=10 \%$ (with the p-value of 0.07 and 0.02 consecutively) in Table 8. Like the case of PSY, the positive effect of K-pop musician on the share of Korean brand automobile sales is more salient vs. 2 US brands case than vs. all 5 brands one. The similar pattern of $\mathrm{CO}$ effect would represent the consumer segment structure in the U.S. market where Korean automobile brands tended to compete more fiercely against US domestic brands than Japanese brands that were included in 5 brands case.

\section{Discussion for future research}

In previous research, surveys have been the most frequently adopted analysis method. However, surveys are structurally limited in measuring the extent of $\mathrm{CO}$ effect on purchase as well as in assessing the strength of corporate brand association with $\mathrm{CO}$. Table 6 demonstrates the brand specific extent of CO effect related to PSY in case of 'Hyundai Sonata'. In the second half of 2013, PSY search index stopped to affect the sales share of 'Hyundai as its index went down to below $4 \%$ of Justin Bieber and Taylor Swift.

Table 8 confirms the existence of $\mathrm{CO}$ effect in case of BTS for 'Hyundai Sonata' in two six-month periods. During that period, the popularity of BTS relative to that of two representative musicians remained at $6.73 \%(2015 \mathrm{H} 1)$ and $16.85 \%(2016 \mathrm{H} 2)$ of them. Unlike PSY, the popularity of BTS continued to grow after the period of positive $\mathrm{CO}$ effect, even overpassing Taylor Swift and Justin Bieber in total searches in the first half of 2018. In case of PSY, the positive $\mathrm{CO}$ effect dissipated because PSY's popularity went below a possible threshold, but the case of BTS is opposite. Our CO effect is captured by taking the variation of popularity and its effect on the sales share cross sectionally across states at a given time frame. As BTS gained popularity, its level across states became more even. The reduced variation across states might have dissipated the positive $\mathrm{CO}$ effect. The following Fig. 4 shows the homogenization of BTS' popularity in US from 2015 to 2016. In 2015 BTS search index had the average of 32.24 in the range from 0 to 100 and the standard deviation of 16.03 where the co-efficient of variation (C.V.) was 0.50 . However, its average and standard deviation became 38.41 and 12.66 consecutively leading its C.V. to be 0.33 . Therefore, the positive $\mathrm{CO}$ effect dissipated not because of its popularity drop but because of its homogenization across states in the case of cross-sectional analysis under a given time frame. This pattern of fandom evolution is quite similar to the diffusion of contagious disease that is outbroken in a specific location then spread to other regions (Fowler and Christakis 2011). Its infection rate gets similar across regions as the time goes by.

Table 7. BTS effect on sales (vs. 5 brands).

\begin{tabular}{|c|c|c|c|c|c|c|c|c|}
\hline \multirow[t]{3}{*}{ Period } & \multicolumn{4}{|c|}{ Hyundai Sonata } & \multicolumn{4}{|c|}{ Kia Optima } \\
\hline & \multirow[t]{2}{*}{ M1_R2 } & \multicolumn{2}{|l|}{ b2 } & \multirow[t]{2}{*}{$\mathrm{R} 2$} & \multirow[t]{2}{*}{ M1_R2 } & \multicolumn{2}{|l|}{ b2 } & \multirow[t]{2}{*}{$\mathrm{R} 2$} \\
\hline & & co-efficient & p-value & & & co-efficient & p-value & \\
\hline $2014 \mathrm{H} 2$ & 0.471 & -0.0006 & 0.98 & 0.471 & 0.249 & -0.0269 & 0.22 & 0.273 \\
\hline $2015 \mathrm{H} 1$ & 0.160 & 0.0434 & 0.16 & 0.194 & 0.127 & -0.0177 & 0.39 & 0.140 \\
\hline $2015 \mathrm{H} 2$ & 0.383 & -0.0118 & 0.66 & 0.386 & 0.327 & -0.0359 & 0.11 & 0.362 \\
\hline 2016H1 & 0.366 & 0.0492 & 0.12 & 0.398 & 0.420 & -0.0043 & 0.84 & 0.421 \\
\hline $2016 \mathrm{H} 2$ & 0.266 & 0.0317 & 0.34 & 0.280 & 0.307 & -0.0073 & 0.78 & 0.308 \\
\hline 2017H1 & 0.433 & -0.0107 & 0.66 & 0.436 & 0.268 & -0.0071 & 0.82 & 0.268 \\
\hline $2017 \mathrm{H} 2$ & 0.538 & 0.0221 & 0.25 & 0.550 & 0.175 & -0.0190 & 0.40 & 0.187 \\
\hline 2018H1 & 0.390 & -0.0079 & 0.78 & 0.391 & 0.143 & -0.0290 & 0.28 & 0.164 \\
\hline $2018 \mathrm{H} 2$ & 0.341 & -0.0194 & 0.45 & 0.349 & 0.150 & -0.0250 & 0.39 & 0.163 \\
\hline
\end{tabular}

*b2 co-efficient is multiplied by 100 for the scale issue. 
Table 8. BTS effect on sales (vs. 2 US brands).

\begin{tabular}{|c|c|c|c|c|c|c|c|c|}
\hline \multirow[t]{3}{*}{ Period } & \multicolumn{4}{|c|}{ Hyundai Sonata } & \multicolumn{4}{|c|}{ Kia Optima } \\
\hline & \multirow[t]{2}{*}{$\overline{M 11 R 2}$} & \multicolumn{2}{|l|}{ b2 } & \multirow[t]{2}{*}{ R2 } & \multirow[t]{2}{*}{ M1_R2 } & \multicolumn{2}{|l|}{$\mathrm{b} 2$} & \multirow[t]{2}{*}{$\mathrm{R} 2$} \\
\hline & & co-efficient & p-value & & & co-efficient & p-value & \\
\hline $2014 \mathrm{H} 2$ & 0.680 & -0.0009 & 0.99 & 0.680 & 0.387 & -0.0013 & 0.99 & 0.387 \\
\hline 2015H1 & 0.575 & 0.1370 & 0.07 & 0.602 & 0.477 & 0.0618 & 0.29 & 0.489 \\
\hline $2015 \mathrm{H} 2$ & 0.674 & 0.0354 & 0.63 & 0.676 & 0.508 & 0.0210 & 0.75 & 0.509 \\
\hline 2016H1 & 0.701 & 0.1520 & 0.02 & 0.732 & 0.559 & 0.0356 & 0.58 & 0.562 \\
\hline $2016 \mathrm{H} 2$ & 0.609 & 0.0560 & 0.46 & 0.613 & 0.484 & 0.0202 & 0.77 & 0.485 \\
\hline 2017H1 & 0.685 & 0.0067 & 0.92 & 0.686 & 0.442 & 0.0902 & 0.21 & 0.460 \\
\hline $2017 \mathrm{H} 2$ & 0.739 & 0.0766 & 0.20 & 0.748 & 0.402 & -0.0128 & 0.87 & 0.402 \\
\hline 2018H1 & 0.627 & 0.0469 & 0.58 & 0.629 & 0.381 & 0.0380 & 0.69 & 0.383 \\
\hline $2018 \mathrm{H} 2$ & 0.580 & 0.0088 & 0.92 & 0.580 & 0.442 & -0.0025 & 0.98 & 0.442 \\
\hline
\end{tabular}

*b2 co-efficient is multiplied by 100 for the scale issue.

Even though both brands are all Korean origin and owned by Hyundai Motor Group, 'Hyundai Sonata' has received a more substantial influence from 'PSY' and 'BTS' in enhancing its market share than 'Kia Optima'. Two brands had a very similar market share ('Hyundai Sonata' 0.106 and 'Kia Optima' 0.094 vs. 5 brands case) over the period of analysis but 'Hyundai Sonata' enjoyed the positive CO effect through PSY and BTS. It is plausible that the strength of association of a brand with that of its country of origin would determine the magnitude of $\mathrm{CO}$ effect in line with the popularity of celebrity from its home country. It means that not all brands from the same country can be equally influenced by $\mathrm{CO}$ effect. As the $\mathrm{CO}$ effect can be either negative (e.g., French nuclear weapon test) or positive (K-pop musicians' popularity), it will depend on the strategic decision of top management to leverage or not the $\mathrm{CO}$ effect. Any marketing manager in charge of a brand regardless of industry type, involvement level, and market scope can assess the strength of his or her brand association with its $\mathrm{CO}$ and decide whether to reinforce its country association or dissociate with its CO.

Therefore, we would like to propose the idea that CO effect would work in two tracks: 1) repeated mere exposures which influence $\mathrm{CO}$ perception over the long term and affect associated brand attitudes in varying degrees of strength (Keller 1993), and 2) intensive temporary exposures sparked by associated objects such as popular musicians which refresh the consumers' memory of $\mathrm{CO}$ perception in the short term without changing brand attitudes. In the case of brand attitude change, the $\mathrm{CO}$ effect would be durable and could be embedded to brands for strengthening their brand equity. However, in the case of memory refresh, the CO effect would only work short term without impact on the equity of corporate brands associated with $\mathrm{CO}$.

We mobilized the Google search index data of two K-pop musicians, PSY and BTS, who hit the US music market, then compared them with purchase data of automobile brand sales to assess the extent of the $\mathrm{CO}$ effect. To generalize our analysis, the country of interest should have a person, an organization, an event, or other that attracts a certain level of attention from consumers in a focal market to use as a proxy variable for analysis. However, it is not always evident to find appropriate objects associated with $\mathrm{CO}$. In that case, our analysis will not be applicable. Even when a country representative object does exist, we are at too early of a research stage to report the minimum level of attention to generate the $\mathrm{CO}$ effect. While it may
2015

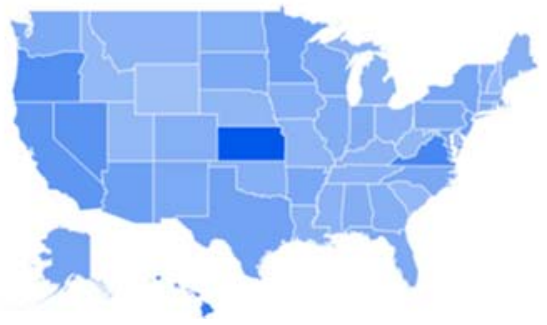

2018

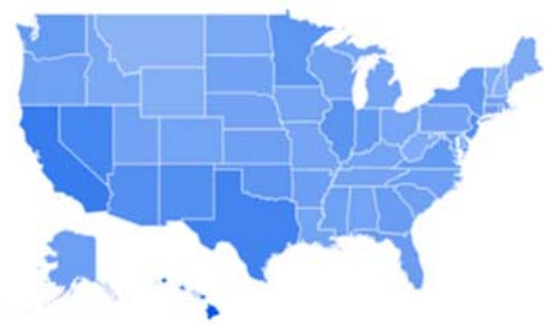

Fig. 4. BTS search index variation. 
appear to be a very managerial question it will nevertheless be an interesting challenge for researchers to find this threshold level across product categories as well as across country markets as more data become available in the near future.

Our analysis was conducted at aggregate level and thus we did not have a chance to capture the $\mathrm{CO}$ effect at sub-region level to explain the possible interaction of the $\mathrm{CO}$ effect with regional characteristics. We hope that our study will open up an opportunity for new research in $\mathrm{CO}$ analysis by using empirical data to measure consumers' interest in $\mathrm{CO}$ as well as the extent of its effect on purchase behavior across product categories as well as across geographical markets.

\section{Conflict of interest}

There is no conflict of interest with any other institute.

\section{Funding}

This work was supported by the Ministry of Education of the Republic of the Korea and National Research Foundation of Korea (NRF-2018S1A5 B6075594).

\section{Acknowledgment}

This work was supported by the Ministry of Education of the Republic of Korea and National Research Foundation of Korea (NRF-2018S1A5B6075594) as well as by Korea University Research Grant.

\section{References}

Alpert, Judy I. and Mark I. Alpert (1990), "Music influences on mood and purchase intentions," Psychology and Marketing, 7 (2), 109-33.

Balabanis, George and Adamantios Diamantopoulos (2011), "Gains and losses from the misperception of brand origin: The role of brand strength and country of origin image," Journal of International Marketing, 19 (2), 95-116.

Batra, Rajeev, Venkatram Ramaswamy, Dana L. Alden, E.M. JanBenedict, Steenkamp, and S. Ramachande (2002), "Effects of brand local/non-local origin on consumer attitudes in developing countries," Journal of Consumer Psychology, 9 (2), 83-95.

Bentzen, Jan and Valdemar Smith (2001), "Did the French nuclear tests under the muroroa atoll affect the export of French wine to Denmark?" working paper Aarhus School of Business Working Papers Series, WP 01-9, ISSN 1397-4831.

$\mathrm{Bu}$, Kyunghee and Whoe Whun Kim (2021), "Is BTS different? Shared episodes on SNS as a good indicator for celebrity endorsed ad effects," Asia Marketing Journal, 22 (4), 27-45.

Court, David, Dave Elzinga, S. Susan Mulder, and Ole Jorgen Vetvik (2009), "The consumer decision journey," McKinsey Quarterly, 1-11. June.

Demirbag, Mehmet, Sunil Sahadev, and Kamel Mellahi (2010), "Country image and consumer preference for emerging economy products: The moderating role of consumer materialism," International Marketing Review, 27 (2), 141-63.

Donabedian, Tvine (2021), "They're worth my investment": Cultivating intimacy through fan-lead financial and support initiatives among BTS fans," Asia Marketing Journal, 22 (4), 103-16.

Dowling, W.Jay and Dane L. Harwood (1986), "Music cognition," Orlando: Academic Press.

Edwards, Ron, Anne-Marie Gut, and Felix Mavondo (2007), "Buyer animosity in business to business markets: Evidence from the French nuclear tests," Industrial Marketing Management, 36 (4), 483-92.

Fournier, Susan (1998), "Consumers and their brands: Developing relationship theory in consumer research," Journal of Consumer Research, 24 (4), 343-73.

Fowler, James H. and Nocholas A. Christakis (2011), "Connected The surprising power of our social networks and how they shape our lives - how your friends' friends' friends affect everything you feel, think," New York: Little, Brown Spark.

Future Brand. (2020), "The Future Brand country index 2020," Available at: https://www.futurebrand.com/uploads/FBCi2020-Assets/FutureBrand-Country-Index-2020.pdf. (accessed January 3, 2022).

Ghose, Anindya and Sha Yang (2009), "An empirical analysis of search engine advertising: Sponsored search in electronic markets," Management Science, 55 (10), 1605-22.

Google. (2011), "Impact of online advertising on consumer packaged goods (CPG) sales: Germany," available at: (accessed January 3, 2022) http://ssl.gstatic.com/think/docs/ impact-of-online-advertising-on-consumer-packaged-goodscpg-sales-germany_research-studies.pdf.

Goldfarb, Avi and Catherine Tucker (2011), "Search engine advertising: Channel substitution when pricing ads to context," Management Science, 57 (3), 458-70.

Gonipath, Shyam, Pradeep K. Chintagunta, and Sriram Venkataraman (2013), "Blogs, advertising, and localmarket movie box office performance," Management Science, 59 (12), 2635-54.

Herz, Marc Florian and Adamantios Diamantopoulos (2013), "Activation of country stereotypes: Automaticity, consonance, and impact," Journal of the Academy of Marketing Science, 41 (4), 400-17.

Heslop, Louise A., R.R. Irene, Lu, and David Cray (2008), "Modeling country image effects through an international crisis," International Marketing Review, 25 (4), 354-78.

Hevner, Kate (1937), "The affective value of pitch and tempo in music," American Journal of Psychology, 49 (4), 621-30.

Josiassen, Alexander and Anne-Wil Harzing (2008), "Descending from the ivory tower: Reflections on the relevance and future of country-of-origin research," European Management Review, 5 (4), 264-70.

Kalyanam, Kirthi (2013), "Proof that online search ads can boost offline store sales," Google thought," available at: (accessed January 3, 2022), https://www.thinkwithgoogle.com/ marketing-strategies/search/proof-online-ads-increaseoffline-sales/.

Kellaris, Jame J., Anthony D. Cox, and Dena Cox (1993), "The effect of background music on ad processing: A contingency explanation," Journal of Marketing, 57 (4), 114-25.

Keller, Kevin L. (1993), "Conceptualizing, measuring, managing customer-based brand equity," Journal of Marketing, 57 (1), 1-22.

Lee, Janghyuk, Kayoon Kim, and Wonseok Woo (2014), "Impact of K-POP on export: Based on YouTube page view and Google search," in Korean Korean Marketing Management Journal, 19 (4), 83-97.

Liefeld, John P. (2004), "Consumer knowledge and use of countryof-origin information at the point of purchase," Journal of Consumer Behaviour, 4 (2), 85-96.

Liu, Scott S., Keith F. Johnson, and Keith F. Johnson (2005), "The automatic country-of-origin effects on brand judgments," Journal of Advertising, 34 (1), 87-97. 
Li, Wai-Kwan and Robert S. Wyer Jr. (1994), "The role of country of origin in product evaluations: Informational and standardof-comparison effects," Journal of Consumer Psychology, 3 (2), 187-212.

Lu, Jing, Dan Wu, Hua Yang, Cheng Luo, Chaoyi Li, and Dezhong Yao (2012), "Scale-free brain-wave music from simultaneously EEG and fMRI recordings," PLoS One, 11. No. 7, pp.e49773. available at: (accessed January 3, 2022), http:// journals.plos.org/plosone/article?id=10.1371/journal.pone. 0049773.

Magnusson, Peter, Stanford A. Westjohn, and Srdan Zdravkovic (2011), “'What, I thought Samsung was Japanese': Accurate or not, perceived country of origin matters," International Marketing Review, 28 (5), 454-72.

Maltby, Matt (2014), "How leading advertisers are using search for brand building." ThinkWithGoogle," available at: (accessed January 16, 2022), https://www.thinkwithgoogle. $\mathrm{com} / \mathrm{marketing-strategies/search/how-advertisers-are-using-}$ search-for-brand-building/.

Maruyama, Masayoshi and Lihui Wu (2014), "The relevance of retailer country-of-origin to consumer store choice: Evidence from China," International Marketing Review, 31 (5), 462-76.

Milliman, Ronald E. (1982), "Using background music to affect the behavior of supermarket shoppers," Journal of Marketing, 46 (3), 86-91.

Milliman, Ronald E. (1986), "The influence of background music on the behavior of restaurant patrons," Journal of Consumer Research, 13 (2), 286-9.

Park, C. Whan and S. Mark Young (1986), "Consumer response to television commercials: The impact of involvement and background music on brand attitude formation," Journal of Marketing Research, 23 (1), 11-24.

Proctor, Jasmine (2021), "Labour of love: Fan labour, BTS, and South Korean soft power," Asia Marketing Journal, 22 (4), 79-101.

Rose, Andrew K. and Mark M. Spiegel (2011), "The Olympic effect," The Economic Journal, 121 (553), 652-77.

Risselada, Hans, Peter C. Verhoef, and Tammo H.A. Bijmolt (2014), "Dynamic effects of social influence and direct marketing on the adoption of high-technology products," Journal of Marketing, 78 (2), 52-68.
Samiee, Saeed, Terence A. Shimp, and Subhash Sharma (2005), "Brand origin recognition accuracy: Its antecedents and consumers' cognitive limitations," Journal of International Business Studies, 36 (4), 379-97.

Sharma, Piyush (2011), "Country of origin effects in developed and emerging markets: Exploring the contrasting roles of materialism and value consciousness," Journal of International Business Studies, 42 (2), 285-306.

Shimp, Terence A. and Subhash Sharma (1987), "Consumer ethnocentrism: Construction and validation of the CETSCALE," Journal of Marketing Research, 24 (3), 280-9.

Smith, N.Craig (1990), "Morality and the market," London: Routledge.

Smith, Patricia C. and Ross Cunrow (1966), "Arousal hypothesis" and the effects of music on purchasing behavior," Journal of Applied Psychology, 50 (3), 255-6.

Steenkamp, Jan-Benedict E.M. (1989), "Product quality. Van gorcum, assen: The Netherlands."

Stout, Patricia A. and John D. Leckenby (1988), "Let the music play: Music as a nonverbal element in television commercials," in Nonverbal communication in advertising, S. Hecker and D.W. Stewart, eds. Lexington: Lexington Books, 207-33.

Usnier, Jean-Claude and Ghislaine Cestre (2007), "Product ethnicity: Revisiting the match between products and countries," Journal of International Marketing, 15 (3), 32-72.

Veale, Roberta and Pascale Quester (2009), "Do consumer expectations match experience? Predicting the influence of price and country of origin on perceptions of product quality," International Business Review, 18 (2), 134-44.

Verlegh, PeterW.J. and Jan-Benedict E.M. Steenkamp (1999), "A review and meta-analysis of country-of-origin research," Journal of Economic Psychology, 20 (5), 521-46.

Wang, Chih-Kang and Charles W. Lamb (1983), "The impact of selected environmental forces upon consumers' willingness to buy foreign products," Journal of the Academy of Marketing Science, 11, 71-84. No. 1/2.

Wang, Xuehua and Zhilin Yang (2008), "Does country-of-origin matter in the relationship between brand personality and purchase intention in emerging economies?" International Marketing Review, 25 (4), 458-74. 